\title{
ACC interleukin-10 gene promoter haplotype as a breast cancer risk factor predictor among Jordanian females
}

This article was published in the following Dove Press journal:

OncoTargets and Therapy

2 June 2016

Number of times this article has been viewed

\author{
Manar Fayiz Atoum \\ Department of Medical Laboratory \\ Sciences, Faculty of Allied Health \\ Sciences, The Hashemite University, \\ Zarqa, Jordan
}

Introduction: Interleukin-10 (IL-10) is a multifactorial cytokine with a complex biological role in breast cancer. The aims of this study were to investigate any association between $I L-10$ gene promoter polymorphisms, $1082 \mathrm{~A}>/ \mathrm{G},-819 \mathrm{~T}>\mathrm{C}$, and $-592 \mathrm{~A}>\mathrm{C}$, or haplotypes and breast cancer risk among Jordanian women and to evaluate any association between the most common haplotype with clinicopathological features of breast cancer.

Patients and methods: A total of 202 breast cancer patients and 210 age-matched healthy control subjects were genotyped for $-1082 \mathrm{~A} / \mathrm{G},-819 \mathrm{~T} / \mathrm{C}$, and $-592 \mathrm{~A} / \mathrm{C}$ single nucleotide polymorphisms in the promoter region of the $I L-10$ gene by polymerase chain reaction-restriction fragment length polymorphism. Study patients and control subjects were recruited from Prince Hamzah Hospital, Amman, Jordan (2012-2013). Ethical approval and signed consent forms were signed by all participants. DNA was extracted, and polymerase chain reaction fragments were amplified and restriction digested by MnII, MaeIII, and RsaI.

Results: This study showed no statistically significant difference between $-1082 \mathrm{~A} / \mathrm{G},-819 \mathrm{~T} / \mathrm{C}$, and $-592 \mathrm{~A} / \mathrm{C} I L-10$ genotypes or alleles among breast cancer patients or controls. Four different haplotypes ATA, ACC, GTA, and ACA within the $I L-10$ promoter gene were determined among both breast cancer and control groups. The most frequent haplotype was ACC among breast cancer patients and controls ( $41.6 \%$ and $40.7 \%$, respectively). No statistical differences in these haplotypes among breast cancer patients or controls were determined. Analysis of the most common ACC haplotype showed statistical difference in positive estrogen receptor $(P=0.022)$, positive progesterone receptor $(P=0.004)$, cancer grade $(P=0.0001)$, and cancer stage $(P=0.009)$ among the ACC haplotype compared to non-ACC haplotype.

Conclusion: To our knowledge, this is the first report studying the association of $I L-10$ haplotype with breast cancer risk events among Jordanian females. The most frequent $I L-10$ haplotype among Jordanian breast cancer females is ACC haplotype. Patients carrying the ACC haplotype are associated with higher positive estrogen and progesterone receptors and advanced breast cancer grade and stage. These patients also had lower survival rate in the Kaplan-Meier survival plot compared to those with non-ACC haplotype.

Keywords: interleukin-10, genotypes, haplotypes, breast cancer

\section{Introduction}

Interleukin-10 (IL-10) is a multifunctional cytokine with both tumor-inhibiting and tumor-promoting properties. ${ }^{1}$ Inflammatory macrophages and mediators of chronic inflammation are highly prevalent in patients with late-stage cancer. IL-10 suppresses macrophage and proinflammatory Th17 T-cell responses by inhibiting the inflammatory cytokines IL-6 and IL-12/23. ${ }^{2}$ IL-10 inhibits proinflammatory cytokine 
production by both $\mathrm{T}$ and NK cells. ${ }^{3}$ Human cancer is characterized by deficits in antigen-specific immunity and intratumoral CD8(+) T-cells. Tumor-promoting properties of IL-10 result from preventing tumor antigen presentation to CD8+ cytotoxic T-lymphocytes by suppressing the expression of major histocompatibility complex class I and II antigens that contribute to the lack of immune response toward transformed cells. ${ }^{4}$ IL-10 induces few mechanisms for effective antitumor immune surveillance: infiltration and activation of intratumoral tumor-specific cytotoxic CD8+ T-cells, expression of the Th1 cytokine interferon- $\gamma$ and granzymes in CD8+ T-cells, and intratumoral antigen presentation molecules. ${ }^{5}$

The $I L-10$ gene consists of five exons located on chromosome 1 (1q31-1q32.50). Approximately 49 genetic polymorphisms have been identified within the $I L-10$ gene, including 46 single nucleotide polymorphisms (SNPs), two microsatellite polymorphisms, and one deletion. Twenty-eight of these polymorphisms are within the $I L-10$ promoter region. ${ }^{1}$ The most important SNPs in the promoter region that influence the transcription of $I L-10$ messenger RNA and the expression of IL-10 in vitro are rs1800896 $(-1082 \mathrm{~A}>\mathrm{G}), \mathrm{rs} 1800871(-819 \mathrm{C}>\mathrm{T})$, and rs $1800872(-592 \mathrm{C}>\mathrm{A}) .{ }^{6}$ The $-1082 \mathrm{~A},-819 \mathrm{~T}$, and $-592 \mathrm{~A}$ haplotypes are associated with decreased $I L-10$ expression compared with $-1082 \mathrm{G},-819 \mathrm{C}$, and $-592 \mathrm{C}$ haplotypes, respectively. ${ }^{7,8}$

Breast cancer is the most common cancer worldwide, with 1.7 million cases diagnosed in 2012. ${ }^{9}$ Over the last 10 years, breast cancer incidence increased progressively in the Middle East and North African population. Mastectomy is performed in $>80 \%$ of Middle East and North African women with breast cancer. ${ }^{10}$ In Jordan, breast cancer is the most common malignancy among women, and according to the Jordanian National Cancer Registry, 864 females and nine males were diagnosed with breast cancer in 2008 , accounting for $18.8 \%$ of the total new cancer cases. Breast cancer ranked the first among Jordanian females, accounting for $36.7 \%$ of all female cancers, and is the leading cause of cancer deaths among Jordanian women. ${ }^{11}$ Breast cancer is an important health issue among Jordanian women because $\sim 37 \%$ of the diagnosed cases were within the advanced stages (III-IV), and the incidence rates are increasing at $4 \%$ per year. ${ }^{11}$ Genetic predisposition to breast cancer in Jordan may be due to consanguineous marriages; however, there is limited literature on Jordanian breast cancer genetics, except for few studies. ${ }^{12,13}$

The biological role of $I L-10$ in cancer is quite complex; however, the presence of IL-10 in advanced metastases and the positive correlation between serum IL-10 levels and progression of the disease indicate a critical role of IL-10 in the tumor microenvironment. ${ }^{14}$ In breast cancer, $I L-10$ may act as a double-edged sword. On the one hand, IL-10 elevation could facilitate cancer by escaping from the immune response, and on the other hand, antiangiogenic effects of IL-10 are supposed to prevent or reduce tumor growth and metastasis. A few case-control studies were conducted to investigate the association between IL-10 -1082A $>\mathrm{G},-819 \mathrm{C}>\mathrm{T},-592 \mathrm{C}>\mathrm{A}$ polymorphisms and breast cancer risk in humans. ${ }^{15,16}$ However, the results of these studies remain conflicting. Hence, the aims of his study were to evaluate the association between IL-10-1082A $>\mathrm{G},-819 \mathrm{C}>\mathrm{T},-592 \mathrm{C}>\mathrm{A}$ polymorphisms or haplotypes and breast cancer risk among Jordanian females and to determine any association between the most common $I L-10$ haplotype, estrogen receptor (ER) expression, progesterone receptor expression, breast cancer grade, and breast cancer stage.

\section{Patients and methods}

This case-control study enrolled 202 breast cancer females from Al-Basheer Hospital, Amman, Jordan (January 2012March 2013) and 210 age-matched controls with no family history of any cancer. All breast cancer patients were diagnosed by a specialized histopathologist; staged according to the National Cancer Institute - National Institutes of Health, USA; and revised by the American Joint Committee on Cancer Staging System for Breast Cancer. ${ }^{17}$ Data recorded by the histopathologist included tumor stages (I, II, III, and IV), grades (I, II, and III), and estrogen and progesterone receptor status.

Ethical approval was obtained from the institutional review board of the The Hashemite University, and a consent form was signed by all participants before interviewing and sample collection. Blood samples were collected in ethylenediaminetetraacetic acid tubes and plain tubes from all participants and controls. Genomic DNA was extracted from peripheral blood leukocytes using Wizard Genomic DNA Extraction and Purification Kit (Promega Corporation, Fitchburg, WI, USA) and then amplified (iCycler; Bio-Rad Laboratories Inc., Hercules, CA, USA) using forward primer $5^{\prime}$-CTCGCTGCAACCCAACTGGC-3' and reverse primer 5'-TCTTACCTATCCCTACTTCC-3' for $-1082 \mathrm{~A} / \mathrm{G}$ SNP, forward primer 5'-TCATTCTATGTGCTGGAGATGG-3' and reverse primer $5^{\prime}$-TGGGGGAAGTGGGTAAGAGT-3' for $-819 \mathrm{~T} / \mathrm{C}$ SNP, and forward primer $5^{\prime}$-GGTGAGCAC TACCTGACTAGC-3' and reverse primer 5'-CCTAGGT 
CACAGTGACGTGG-3' for -592A/C SNP. Polymerase chain reaction amplification was carried out in $50 \mu \mathrm{L}$ reaction mixture using GoTaq Green Master Mix (Promega Corporation), containing thermostable Taq polymerase deoxynucleotide. Polymerase chain reaction profile consisted of initial melting step of 5 minutes, followed by 35 cycles of 30 seconds at $94^{\circ} \mathrm{C}, 45$ seconds at $58^{\circ} \mathrm{C}$ for $-1082 \mathrm{~A}>/ \mathrm{G}$, $59^{\circ} \mathrm{C}$ for $-819 \mathrm{~T}>\mathrm{C}$, and $62^{\circ} \mathrm{C}$ for $-592 \mathrm{~A}>\mathrm{C}$; $55 \mathrm{sec}-$ onds at $72^{\circ} \mathrm{C}$, and final elongation at $72^{\circ} \mathrm{C}$ for 8 minutes. Restriction endonucleases MnII, MaeIII, and RsaI were used to distinguish $-1082 \mathrm{~A}>\mathrm{G},-819 \mathrm{~T}>\mathrm{C}$, and $-592 \mathrm{~A}>\mathrm{C}$, respectively.

Chi-squared test was used to compare genotype and allele frequencies among breast cancer cases and controls. Statistical significance was assumed at $P<0.05$. Clinicopathological data were compared by chi-squared test and student's $t$-test to show any statistical difference between positive ER, positive progesterone receptor, breast cancer grade, and breast cancer stage among ACC versus non-ACC patients. ACC and non-ACC patient survival was assessed by Kaplan-Meier survival curve in Excel.

\section{Results}

Genotype and allele frequencies for $I L-10$ polymorphisms $-1082 \mathrm{~A}>\mathrm{G},-819 \mathrm{C}>\mathrm{T}$, and $-592 \mathrm{C}>\mathrm{A}$ among breast cancer patients and control groups are shown in Table 1. Both genotypes and alleles were within the Hardy-Weinberg equation. No statistically significant difference in genotype or allele frequencies at all SNP sites was observed between breast cancer patients and healthy controls.

The haplotype frequencies for $I L-10$ polymorphisms $(-1082,-819$, and -592$)$ are shown in Table 2. Four haplotypes (ATA, ACC, GTA, ACA) were demonstrated in this study. The most frequent haplotype for both breast cancer patients and controls was ACC, with $41.6 \%$ frequency in patients versus $40.7 \%$ in controls. No statistical difference in haplotype frequencies was observed between breast cancer patients and controls.

Analysis of breast cancer predictive factors (Table 3) revealed significant association between ACC haplotype with positive ER $(P=0.022)$, positive progesterone receptor ( $P=0.004)$, advanced breast cancer grade $(P=0.0001)$, and advanced breast cancer stage $(P=0.009)$ compared to nonACC haplotype.

The Kaplan-Meier survival plot for breast cancer patients over a 16-month follow-up showed higher survival rate among non-ACC haplotype compared to ACC haplotype (Figure 1).

\section{Discussion}

This case-control study was conducted to evaluate any association between $I L-10$ promoter polymorphism and breast cancer risk among Jordanian population. The results showed no significant association between $I L-10-1082 \mathrm{~A}>\mathrm{G},-819 \mathrm{C}>\mathrm{T}$, and $-592 \mathrm{C}>\mathrm{A}$ polymorphisms and breast cancer risk among alleles, genotypes, or haplotypes. These results were inconsistent with the results among Italian population, ${ }^{18}$ which showed increased breast cancer risk among $I L-10-1082$ genotype, and the results among Australian population, ${ }^{19}$ in which -592AA was associated with reduced breast cancer risk. However, these results are consistent with the results reported by Zou et $\mathrm{a}^{15}$ who showed lack of association between the two SNPs $(1082 \mathrm{~A}>\mathrm{G},-592 \mathrm{C}>\mathrm{A})$ in the $I L-10$ promoter and breast cancer and those reported by Kong et $\mathrm{al}^{20}$ among Chinese population. The inconsistency may be due to differences in ethnic background, genetics, and sample size.

Table I Genotype and allele frequencies of IL-IO polymorphisms $(-1082,-819,-592)$ in breast cancer patients and healthy controls

\begin{tabular}{|c|c|c|c|c|c|c|c|}
\hline Genotype & $\begin{array}{l}\text { Patient } \\
(\mathrm{N}=202), \mathrm{n}(\%)\end{array}$ & $\begin{array}{l}\text { Control } \\
(\mathrm{N}=2 \mid 0), n(\%)\end{array}$ & $P$-value & Allele & $\begin{array}{l}\text { Patient } \\
(2 N=404), n(\%)\end{array}$ & $\begin{array}{l}\text { Control } \\
(2 \mathrm{~N}=420), n(\%)\end{array}$ & $P$-value \\
\hline$-1082 A / G$ & & & & $-1082 A / G$ & & & \\
\hline AA & I57 (77.7) & I5I (7I.9) & 0.305 & A & $343(84.9)$ & 344 (81.9) & 0.248 \\
\hline AG & $29(14.4)$ & $42(20)$ & & G & $61(15.1)$ & $76(18.1)$ & \\
\hline GG & $16(7.9)$ & $17(8.1)$ & & & & & \\
\hline$-819 \mathrm{~T} / \mathrm{C}$ & & & & $-819 \mathrm{~T} / \mathrm{C}$ & & & \\
\hline TT & $88(43.5)$ & $93(44.3)$ & 0.619 & $\mathrm{~T}$ & $223(55.2)$ & $227(54)$ & 0.740 \\
\hline TC & $47(23.3)$ & 41 (19.5) & & $C$ & I8I (44.8) & $193(46)$ & \\
\hline $\mathrm{CC}$ & $67(33.2)$ & $76(36.2)$ & & & & & \\
\hline$-592 \mathrm{~A} / \mathrm{C}$ & & & & $-592 \mathrm{~A} / \mathrm{C}$ & & & \\
\hline $\mathrm{AA}$ & $76(37.6)$ & $79(37.6)$ & 0.891 & A & $236(58.4)$ & $249(59.3)$ & 0.800 \\
\hline$A C$ & $84(4 \mid .6)$ & 91 (43.3) & & C & I68 (4I.6) & I7I (40.7) & \\
\hline $\mathrm{CC}$ & $42(20.8)$ & $40(19.1)$ & & & & & \\
\hline
\end{tabular}

Abbreviation: IL-10, interleukin-10. 
Table 2 Haplotype frequencies of IL-10 polymorphisms (-1082, $-819,-592)$ among breast cancer patients and healthy controls

\begin{tabular}{lllll}
\hline Haplotype & $\begin{array}{l}\text { Patient } \\
(\mathbf{N}=\mathbf{4 0 4}), \mathbf{n}(\%)\end{array}$ & $\begin{array}{l}\text { Control } \\
\mathbf{( N = 4 2 0 )}, \mathbf{n}(\%)\end{array}$ & $\chi^{2}$ & P-value \\
\hline ATA & $162(40.1)$ & I5I (36) & 4.06 & 0.255 \\
ACC & I68 (4I.6) & I7I (40.7) & & \\
GTA & $61(15.1)$ & $76(18.1)$ & & \\
ACA & $13(3.2)$ & $22(5.2)$ & & \\
\hline
\end{tabular}

Abbreviation: IL-10, interleukin-10.

This study showed the presence of four haplotypes within $I L-10-1082 \mathrm{~A}>\mathrm{G},-819 \mathrm{C}>\mathrm{T}$, and $-592 \mathrm{C}>\mathrm{A}$ polymorphisms. The most frequent haplotypes were ACC and ATA among breast cancer patients $(40.6 \%, 40.1 \%)$ and controls $(40.7 \%, 36 \%)$, respectively. These frequencies are higher than the frequencies recorded among Italians ${ }^{21}$ which were $16 \%$ and $16 \%$ for ACC and ATA, respectively, and among Canadians, ${ }^{22}$ which were $16 \%$ and $14.4 \%$, respectively, and were similar to ACC frequency among German population (39.7\%); but higher than the ATA frequency $(16.2 \%)$ recorded by Reichert et al. ${ }^{23}$ These differences may be due to differences in ethnic backgrounds among these populations.

This study showed that ACC haplotype was associated with positive ER, positive progesterone receptor, advanced breast cancer grade, and advanced breast cancer stage. Hence, ACC $I L-10$ promoter gene haplotype may be considered as one of the risk factors for breast cancer among Jordanians. This haplotype may decrease $I L-10$ expression within breast cancer cells, since higher $I L-10$ expression in tumor cell cytoplasm was associated with lower $\mathrm{T}$ grade, positive ER,

Table 3 IL-IO haplotype frequencies and pathological features among breast cancer females

\begin{tabular}{|c|c|c|c|c|c|}
\hline Pathological feature & $\mathbf{N}$ & ACC, $n$ & Non-ACC, n & $\chi^{2}$ & $P$-value \\
\hline \multicolumn{6}{|l|}{ ER } \\
\hline Positive & 218 & 102 & 116 & 5.28 & 0.022 \\
\hline Negative & 186 & 66 & 120 & & \\
\hline \multicolumn{6}{|l|}{ Progesterone receptor } \\
\hline Positive & 224 & 79 & 145 & 8.26 & 0.004 \\
\hline Negative & 180 & 89 & 91 & & \\
\hline \multicolumn{6}{|l|}{ Cancer grade } \\
\hline Grade I & 124 & 18 & 106 & 54.7 & 0.0001 \\
\hline Grade II & 113 & 57 & 56 & & \\
\hline Grade III & 167 & 93 & 74 & & \\
\hline \multicolumn{6}{|l|}{ Cancer stage } \\
\hline Stage I & 14 & 9 & 5 & 16.35 & 0.009 \\
\hline Stage II & 67 & 37 & 30 & & \\
\hline Stage III & 114 & 34 & 80 & & \\
\hline Stage IV & 209 & 74 & 135 & & \\
\hline
\end{tabular}

Abbreviations: IL-10, interleukin-I0; ER, estrogen receptor.

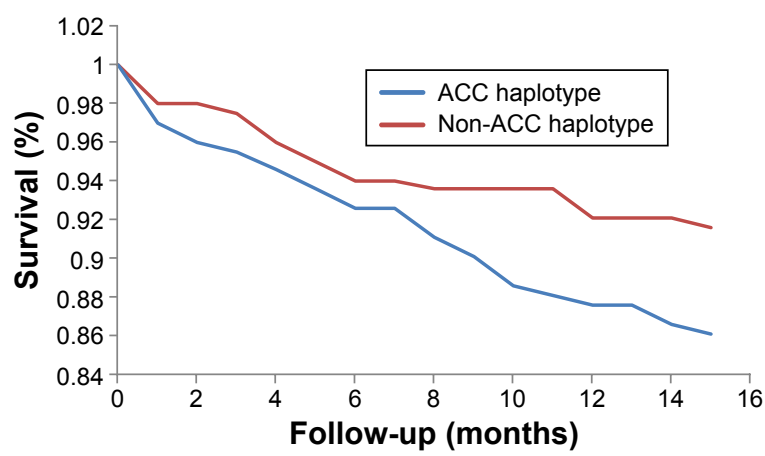

Figure I A Kaplan-Meier survival plot showing difference in survival probability among ACC- versus non-ACC-haplotyped breast cancer patients.

and negative vascular invasion. ${ }^{24}$ The precise mechanism by which $I L-10$ promoter polymorphism modulates breast cancer progression is unknown, but it may modulate the immune system, natural killer cells, T-cells, and macrophages, or it may derepress the angiogenic effect and promote cancer. ${ }^{25}$ Predicting breast cancer risk is of great interest in medical research; therefore, genetic assessment in normal patients may predict the risk of breast cancer using haplotypes and clinicopathological picture. More research on $I L-10$ haplotypes could help to decide whether it is possible to use haplotypes and clinicopathological picture to predict the cancer outcome and the treatment.

\section{Acknowledgments}

I would like to acknowledge The Hashemite University for providing financial support to this project and the workers of Hamzeh University and Al-Basheer Hospital for helping me in sample collection.

\section{Disclosure}

The author reports no conflicts of interest in this work.

\section{References}

1. MW Howell [webpage on the Internet]. Interleukin-10 Gene Polymorphisms and Cancer. Available from: http://www.ncbi.nlm.nih.gov/books/ NBK6117. Accessed November 28, 2015.

2. Oft M. IL-10: master switch from tumor-promoting inflammation to antitumor immunity. Cancer Immunol Res. 2014;2(3):194-199.

3. de Waal Malefyt R, Haanen J, Spits H, et al. IL-10 and viral IL-10 strongly reduce antigen-specific human $\mathrm{T}$ cell proliferation by diminishing the antigen-presenting capacity of monocytes by downregulation of class II MHC expression. J Exp Med. 1991;174(4):915-924.

4. Matsuda M, Salazar F, Petersson M, et al. Interleukin 10 pretreatment protects target cells from tumor- and allo-specific cytotoxic T cells and downregulates HLA class I expression. J Exp Med. 1994;180(6): 2371-2376.

5. Mumm JB, Emmerich J, Zhang X, et al. IL-10 elicits IFN $\gamma$-dependent tumor immune surveillance. Cancer Cell. 2011;20(6):781-796.

6. Jasenka Trifunović, Larisa Miller, Željko Debeljak, Vesna Horvat. Pathologic patterns of interleukin 10 expression - A review. Biochem Med (Zagreb). 2015;25(1):36-48. 
7. Turner DM, Williams DM, Sankaran D, Lazarus M, Sinnott PJ, Hutchinson IV. An investigation of polymorphism in the Interleukin-10 gene promoter. Eur J Immunogenet. 1997;24(1):1-8.

8. Gerger A, Renner W, Langsenlehner T, et al. Association of interleukin-10 gene variation with breast cancer prognosis. Breast Cancer Res Treat. 2010;119(3):701-705.

9. World Cancer Research Fund International [webpage on the Internet]. Breast Cancer Statistics. Available from: http://www.wcrf.org/int/ cancer-facts-figures/data-specific-cancers/breast-cancer-statistics. Accessed November 28, 2015.

10. Mahfoudh W, Bouaouina N, Ahmed SB, et al. Hereditary breast cancer in Middle Eastern and North African (MENA) populations: identification of novel, recurrent and founder BRCA1 mutations in the Tunisian population. Mol Biol Rep. 2012;39(2):1037-1046.

11. Jordan Breast Cancer program [homepage on the Internet]. Under Renovation. Available from: http://www.jbcp.jo. Accessed November 28, 2015.

12. Atoum MF, Tanashat RQ, Mahmoud SA. Negative association of the HLA-DQB1*02 allele with breast cancer development among Jordanians. Asian Pac J Cancer Prev. 2014;15(17):7337-7341.

13. Atoum M, Abdel-Fattah M, Nimer N, Abdel-Rahman S, Abdeldayem SA. Association of alanine-valine manganese superoxide dismutase gene polymorphism and microheterogeneity manganese superoxide dismutase activity in breast cancer and benign breast tissue. J Breast Cancer. 2012;15(2):157-161.

14. Sato T, Terai M, Tamura Y, Alexeev V, Mastrangelo MJ, Selvan SR. Interleukin 10 in the tumor microenvironment: a target for anticancer immunotherapy. Immunol Res. 2011;51(2-3):170-182.

15. Zou YF, Wang F, Feng XL. Lack of association between two SNPs (rs1800896 and rs1800872) in IL-10 gene promoter and breast cancer in Caucasians. Breast Cancer Res Treat. 2011;125(1):291-293.
16. Yu KD, Chen AX, Yang C, Fan L, Huang AJ, Shao ZM. The associations between two polymorphisms in the interleukin-10 gene promoter and breast cancer risk. Breast Cancer Res Treat. 2012;131(1):27-31.

17. NIH [webpage on the Internet]. Breast Cancer Treatment-Health Professional Version (PDQ $\left.{ }^{\circledR}\right)$. Available from: http:/www.cancer.gov/ cancertopics/pdq/treatment/breast/healthprofessional/page3. Accessed November 28, 2015

18. Giordani L, Bruzzi P, Lasalandra C, et al. Association of breast cancer and polymorphisms of interleukin-10 and tumor necrosis factor-alpha genes. Clin Chem. 2003;49(10):1664-1667.

19. Langsenlehner U, Krippl P, Renner W, et al. Interleukin-10 promoter polymorphism is associated with decreased breast cancer risk. Breast Cancer Res Treat. 2005;90(2):113-115.

20. Kong F, Liu J, Liu Y, Song B, Wang H, Liu W. Association of interleukin-10 gene polymorphisms with breast cancer in a Chinese population. J Exp Clin Cancer Res. 2010;29:72.

21. Lio D, Licastro F, Scola L, et al. Interleukin-10 promoter polymorphism in sporadic Alzheimer's disease. Genes Immun. 2003;4(3):234-238.

22. Sanchez R, Levy E, Costea F, Sinnett D. IL-10 and TNF-alpha promoter haplotypes are associated with childhood Crohn's disease location. World J Gastroenterol. 2009;15(30):3776-3782.

23. Reichert S, Machulla HK, Klapproth J, et al. The interleukin-10 promoter haplotype ATA is a putative risk factor for aggressive periodontitis. J Periodontal Res. 2008;43(1):40-47.

24. Li Y, Yu H, Jiao S, Yang J. [Prognostic value of IL-10 expression in tumor tissues of breast cancer patients]. Xi Bao Yu Fen Zi Mian Yi Xue Za Zhi. 2014;30(5):517-520.

25. Liu J, Song B, Bai X, et al. Association of genetic polymorphisms in the interleukin-10 promoter with risk of prostate cancer in Chinese. BMC Cancer. 2010;10:456.
OncoTargets and Therapy

\section{Publish your work in this journal}

OncoTargets and Therapy is an international, peer-reviewed, open access journal focusing on the pathological basis of all cancers, potential targets for therapy and treatment protocols employed to improve the management of cancer patients. The journal also focuses on the impact of management programs and new therapeutic agents and protocols on

\section{Dovepress}

patient perspectives such as quality of life, adherence and satisfaction. The manuscript management system is completely online and includes a very quick and fair peer-review system, which is all easy to use. Visit http://www.dovepress.com/testimonials.php to read real quotes from published authors. 